\title{
Recent Upsurge in Sectarianism in Pakistan: Understanding the Sunni-Shia Divide as a Case-study of Inter-Group Rivalry and the Role of Ultra-Right Parties
}

\author{
Maheen Ahmad
}

\begin{abstract}
There is a heightened concern in Pakistan over the rise of violent sectarianism, which has been pitting certain sections of denominational groups against each other, often assuming violent proportions. At the forefront of this renewed phase with a strong antiShia sentiment is the role of hate-spewing divisive elements, more specifically ultra-right elements that are exacerbating an exaggerated division between Sunni and Shia Muslims for their own political motives. If their momentum is sustained, then the risk is that they can further radicalize the mainstream and lodge one group against the other, putting them in a perpetual state of animosity, whereby Pakistani citizens may experience intense and implosive antagonism. This paper attempts to explain this emerging scenario in the light of theoretical frameworks of social and cognitive psychology underpinning inter-group dynamics and offers certain lessons from the erstwhile Hutu/Tutsi divide in the Rwandan Genocide of the 1990 s.
\end{abstract}

Keywords: Ultra-Right Positions, Sectarianism, Extremism, Social Identity, Inter-group Rivalry.

\footnotetext{
* Maheen Ahmad is Assistant Research Associate at Islamabad Policy Research Institute (IPRI), Islamabad. She can be reached at maheen.ahmad@ipripak.org
}

@2021 by the Islamabad Policy Research Institute.

IPRI Journal $\square$ XXI (2): 177-192

https://doi.org/10.31945/iprij.210207 

Recent Upsurge in Sectarianism in Pakistan: Understanding the ...

\section{Introduction}

$\mathrm{P}$

akistan is home to a fusion of diverse ethnicities and ideational

clusters, bringing together people with varied cultural, linguistic, and even religious and denominational identities. Pakistan is predominantly a Muslim country, with approximately eighty per cent of Pakistanis adhering to Sunni Islam. ${ }^{1}$ While Pakistan is the second largest home to Shia community (after neighboring Iran), it is still an understood fact that the Shia community in Pakistan is proportionately smaller, constituting only ten to fifteen per cent of the population. ${ }^{2}$ The rise in sectarian instances in the time period between 2020 and 2021 in Pakistan, during which Mufti Saleemullah Khan, a religious scholar was shot and wounded in a suspected sectarian attack in April of 2021. ${ }^{3}$ It may point to a renewed wave of anti-Shia sentiment surfacing in the country. Nothing could have been made more apparent than the recent 'Azmat-eSahaba' rallies involving around 30,000 people, who came to streets in Karachi in September 2020 with the rallying cry against Shia Muslims. ${ }^{4}$ It was the largest anti-Shia march seen in decades in Pakistan and was replicated in other cities, including the capital, Islamabad.

\section{Sectarianism in Pakistan: its Proponents, History and Causes}

Pakistan is no stranger to sectarian violence. As per South Asia Terrorism Portal, sectarian violence in Pakistan was at its peak in the 1990s. Around 300 such incidents took place. Similarly, in 2007, 341 terrorist attacks of this type were recorded. ${ }^{5}$

\footnotetext{
${ }^{1}$ Muhammad F. Jamil and Tayyaba Sohail, "Group Conformity And Individuals' Behavior Towards Adopting Sectarian Identities," Burjis, 6, no. 1 (2019): 02.

${ }^{2}$ Saima Afzal, Hamid Iqbal, and Mavara Inayat, "Sectarianism and Its Implications for Pakistan Security: Policy Recommendations Using Exploratory Study," IOSR: Journal for Humanities and Social Science 4, no. 4, (January 2012): 12.

${ }^{3}$ News Desk, "Religious scholar shot at, wounded in 'sectarian' attack in Karachi," Dawn, April 1, 2021.

${ }^{4}$ Kalbe Ali, "Banned outfit's leader booked for fanning sectarianism at Islamabad rally," Dawn, September 19, 2020.

${ }^{5}$ South Asia Terrorism Portal, "Sectarian Violence in Pakistan," South Asia Terrorism Portal, last modified November 8, 2020.
} 


\section{Maheen Ahmad}

\section{Proponents of Sectarianism}

Sectarianism has taken ugly and violent shapes and forms in Pakistan. There is said to be six major violent sectarian groups that have operated in Pakistan namely:

i. Lashkar e Jhangvi (LeJ);

ii. Sipha-e-Muhammad (SeM);

iii. Jaishul Adal (JA);

iv. Lashkar-e-Islam, (LI);

v. Ansarul Islam (AI);

vi. Sunni Tehrik(ST).

All these groups brought a sectarian hue to their movements, operating in areas across Pakistan including Karachi, Quetta, Rawalpindi, former Khyber Agency, urban Sindh, Southern Punjab and Balochistan. ${ }^{6}$ While four have been banned, the staunchest of the abovementioned include LeJ and SeM, whose underground cadres remain operative across the regions often waiting for their operational chance. The LeJ has a very violent antiShia agenda, targeting Shias in Pakistan and in Afghanistan. ${ }^{7}$ Claiming to be a breakaway faction of the Sipah-e-Sahaha Pakistan (SSP), an-anti Shia sectarian group now known as the Ahle Sunnat wal Jamaat, the LeJ has furthered the cause of the SSP. ${ }^{8}$ However, it still depends greatly on the SSP for human resources and financial support. The group is also known to have affiliations with different militant outfits such as Daesh, Al-Qaeda and Tehrik-e-Taliban Pakistan (TTP). Although the group was proscribed in 2000, many of its splinter groups have formed ever since under newer names and disparate bases.

${ }^{6}$ Mohammad A. Rana, The Militant: Development of a Jihadi Character in Pakistan, (Lahore: Narratives, 2015), 159.

${ }^{7}$ Khuram Iqbal, "Chapter III - The Global and the Local," in United by Violence, Divided by Cause? (Baden, Germany: Nomos Verlagsgesellschaft mbH \& Co., 2021), 157.Iqbal, "The Global and the Local," 157.

${ }^{8}$ Iqbal, "The Global and the Local," 157. 
Recent Upsurge in Sectarianism in Pakistan: Understanding the ...

The Sipah-e-Muhammad is another sectarian group in Pakistan, which is said to be Iran's proxy operating in the country as a militant agency for Shia elements. The group is estimated, as per Pakistani intelligence sources, to have around 5,000 fighters. ${ }^{9}$ It has an active wing by the name of 'Zainabyoon' which is known to have operated in Syria against antiBashar-Al-Asad forces. ${ }^{10}$ Some experts caution that the Zainabyoon has a potential of engaging in an active sectarian confrontation with Deobandi LeJ and also has the wherewithal for creating unrest and instability in the country through street protests, in order to harm American interests in Pakistan, at the behest of Iran. ${ }^{11}$

\section{History of Sectarianism in Pakistan}

Many experts argue that historical schism is an original driving factor behind present-day tensions, basically dating as far back as the Battle of Karbala. However, this is simply just one side of the coin. A closer reading of the past demonstrates far more instances of cohabitation between the Sunni and Shia sects than instances of conflict and mistrust. Just think back to the periods ruled by the Sunni Ottoman Empire and the Shia Safavid Empire, in which there was generally higher religious tolerance within Islam. While the Safavids and Ottomans fought for generations, religion was seldom used to underwrite such hostilities. In fact, Sunni-Shia conflicts were largely uncommon during the period of British India. $^{12}$

In Pakistan specifically, sectarianism remained a relatively ignored issue in its early years. The society of Pakistan was not predominantly characterized by opposing violent sectarian tendencies and the relationship between Sunni and Shia sects remained cordial. ${ }^{13}$ It was only in the mid-1950s' that early signs of Shia-Sunni clashes surfaced in

\footnotetext{
9 Iqbal, "The Global and the Local," 157.

${ }^{10}$ Ibid.

${ }^{11}$ Ibid.

${ }^{12}$ Majeed, "A Historical Account of Sectarianism in Pakistan," 390.

${ }^{13}$ Ibid.
} 


\section{Maheen Ahmad}

Punjab. These clashes broke out on the Sunni religious clerics' opposition to large Shia processions held in Muharram. Instances of anti-Shia violence began sprouting up in the late 1950s' and the early 1960s, spearheaded primarily as a result of an attack on a Shia procession in Khairpur, Sindh. Eventually, Punjab saw sectarian violence increase in the 1980s', especially when an anti-Shia outfit known as Sipah-e-Sahaba was established, it achieved some electoral success in Punjab. Despite its local roots linked with politics in Jhang and competition between the Shia landlord and Sunni groups, this organization rivalled the Shia organization known as Tehreek-e-Nifaz-e-Fiqah-e-Jafariya (TNFJ) and had even gone to demanding that the General Ziaul Haq regime, at that time should declare Pakistan an overtly Sunni state and pronounce Shia as non-Muslim. Given the popularity of Ayatollah Khomeini among Pakistani Shia groups following the Iranian revolution, places like Jhang and Parachinar saw intensity in the denominational reconfiguration. The ensuing Saudi-Iranian rivalry often assuming proxy proportions on Pakistani soil, Shia-Sunni polarity assumed newer and no less horrendous dimensions. Coinciding these developments, Zakat was imposed which was to be collected from people's bank accounts. However, Shia and Sunni schools of law differ in their stipulations on Zakat, and therefore, this policy decision to impose tax created intense resentment among the Shia community and served as a catalyst towards their political mobilization in Pakistan. ${ }^{14}$

As a response to the growth of the ASSP, a radical Shia organization called Sipah-e-Mohammad Pakistan (SMP/SeM) emerged which undertook killing of members from opposite sect. ${ }^{15}$ Eventually, a Wahabbi awakening picked up momentum, and mainly after 2001 (and the September 11 attacks), sectarian consciousness in Pakistan reached levels it had not witnessed before. ${ }^{16}$ It was at this time that even Sunni

${ }^{14}$ Muhammad Q. Zaman, "Sectarianism in Pakistan: The Radicalization of Shi'i and Sunni Identities," Modern Asian Studies 32, no. 3 (1998).

${ }^{15}$ Majeed, "A Historical Account Of Sectarianism In Pakistan,"391.

${ }^{16}$ Rana, The Militant, 159. 
Recent Upsurge in Sectarianism in Pakistan: Understanding the ...

families began dividing themselves into Barelvi and Deobandi Muslims making Muslimness into a contested terrain of competing identities and polarized opinions

\section{Causes of Sectarianism in Pakistan}

How sectarian divisions deepened over the years can be explained through a number of factors. Some experts argue that the primary reason of sectarian ideas gained a foothold in Pakistan due to foreign funding to sectarian leadership and the proxy extremism and intellectual input being provided by Saudi Arabia, Iran and the Gulf states. Others suggest that there was a heavy blowback influence of the Afghan jihad and the Iranian revolution, as well as General Zia's policies at home. ${ }^{17}$ Newer explanations attribute the intensity of sectarian conflicts to the increased accessibility of the digital space through which sectarian elements have found a secure, far reaching and effective voice enabling it to drum up support among younger and more impressionable minds. ${ }^{18}$

\section{The Sunni-Shia Divide through the Lens of Psychology}

What is seldom factored in when examining the Sunni-Shia divide, is simple and plain psychology. The Sunni-Shia clash in Pakistan is an example of inter-group rivalry, whereby one group forms an impressionable opinion of the other, simply because they perceive them differently. Significant research in social sciences reveals that differences in ideologies, traditions and norms between groups and societies can provoke conflict. ${ }^{19}$ Discrimination and prejudice are grounded in notions of group identity and group conflict tied with the concepts of the 'out group' and the 'in group. ${ }^{20}$

\footnotetext{
${ }^{17}$ Majeed, "A Historical Account Of Sectarianism In Pakistan,"389.

${ }^{18}$ Gulshan Majeed, "A Historical Account of Sectarianism In Pakistan And Persecution Of Shia Hazara Community Of Quetta In Balochistan," Pakistan Social Sciences Review 5 (2021): 385 .

${ }^{19}$ Linda Tropp, The Oxford Handbook of Intergroup Conflict (New York: Oxford University Press, 2012), 152.

${ }^{20}$ Michelle Adams, "Intergroup Rivalry, Anti-Competitive Conduct and Affirmative Action," Boston University Law Review 82, no. 5 (2002): 1098.
} 


\section{Maheen Ahmad}

The in-group imagery is made of a number of collective individuals that share norms and values. On the basis of this identity, they form a perception and bias in favor of their own group which may stem from sheer self-interest, misinformation and simply by virtue of some 'territorial' claim. Discrimination takes root when this group of people starts considering themselves superior to the out-group, who as a medley of people are seemingly different from them. Interestingly enough, it is often the case that in several areas, people are not very different. Still, these flash judgements and opinions are made and that forms the basis of prejudice. Identity of the group, which is in essence the extent to which group members identify with one another and share commonalities with one another, is therefore a key motivating factor for the perpetuation of intergroup conflict. ${ }^{21}$

Research on intergroup conflict reveal that in-groups and out-groups form through the mere categorization of the creation of groups. Loyalty to the group, even within groups without recognizable commonalities, can form very quickly which may be linked to some kind of innate tribal instinct among human beings. That is why ethnicity is unsurprisingly a powerful and easily identifiable identity, given the possibility of commonalities such as shared cultures, histories, language, religion, and worldviews acquired over a long time. ${ }^{22}$

On a larger scale, history is testament to the number of conflicts that were based primarily on ethnic, religious and racial differences. The genocide in Darfur to divisions in Northern Ireland, tensions between the Sinhalese and Tamils in Sri Lanka, and dissension between Israelis and Palestinians in Gaza, could be seen as varied manifestation of such collective trajectories. ${ }^{23}$ In such conflicts, the negative and exclusionary categorization of people provides a psychological authorization and

21 Tropp, Oxford Handbook, 159.

${ }^{22}$ Omar S. McDoom, "The Psychology of Threat in Intergroup Conflict: Emotions, Rationality, and Opportunity in the Rwandan Genocide," International Security 37, no. 2 (2012): 135

23 Tropp, Oxford Handbook, 152. 
Recent Upsurge in Sectarianism in Pakistan: Understanding the ...

rationale for engaging in conflict and causing intentional harm to others. ${ }^{24}$ Sometimes, it can be observed that groups in conflict often have different views of the past and distinct narratives regarding the histories of relations between their groups. This explains why groups in conflict often emerge with their own respective and certainly conflicting narratives of the past events. Divergent views of historical events, among other factors, therefore, fuel intergroup conflict. ${ }^{25}$

\section{The Role of Ultra-Right Wing Parties in Exacerbating Sunni/Shia Divide}

Let us apply the theory of inter-group rivalry into the case-study of Pakistan's Shia and Sunni division. As of late, ultra-right parties are emboldened and have assumed a center-stage across Pakistani political spectrum. Rightwing parties exacerbate a false division between Sunnis and Shias and fuel hatred by the same inter-group dynamics that this paper referred to in the previous section.

Relevant to understand is how in-grouping and out-grouping is carried out by ultra-right parties. In practice, the parties ostracize the out-group and become favorable only to in-group members. At the forefront of the latest anti-Shia campaign are their rallying cries and power-plays by some of the Sunni rhetoricians. One such party is the Tehreek-e-Labbaik Pakistan (TLP), a political party that participated in the 2018 general elections and acquired seats in the Sindh Assembly. ${ }^{26}$ This party is grounded in its beginnings as a 'Tehreek Rihai Mumtaz Qadri' movement, which was renamed as 'Tehreek-e-Labaik Ya Rasoolullah' after the hanging of Mumtaz Qadri.

Another such party is the Ahl-e-Sunnat Wal Jamaat (ASWJ). These parties have assembled crowds, carried out rallies, and have delivered public and blatant anti-Shia speeches. Khadim Rizwi, the erstwhile leader

${ }^{24}$ Tropp, Oxford Handbook, 155.

${ }^{25}$ Ibid. 161.

${ }^{26}$ Arshad Yousafzai, "TLP wins two Sindh Assembly seats from Karachi," The News, July 27, 2018. 


\section{Maheen Ahmad}

of TLP, was quoted in many of his sermons inciting anti-Shia sentiments which is a blatant attack on Shia sentiments. His sermons challenge their perspective on history and their practices. ${ }^{27} \mathrm{~A}$ central leader of the ASWJ had a First Information Report (FIR) registered against him for inciting the attendees of a rally by using sectarian and anti-Shia remarks. He was booked under Section 295-A (deliberate and malicious acts intended to outrage religious feelings of any class by insulting its religion or religious beliefs) of the Pakistan Penal Code. ${ }^{28}$ So, what is the agenda of such rightwing parties?

Historically, mainstream religio-political parties have performed poorly in Pakistan's electoral politics. They normally exercise their influence through organized street pressure to oblige the government and accede to their demands. Such extremist religious-political movements-turned parties, like the TLP bear the growing tendency to achieve political goals through violent expressions of their demands. Over the years, religiopolitical parties have exploited socio-economic grievances of the people in order to attract mass support for their narratives. Socioeconomic grievances, coupled with religious zealotry, can make a combustible mix, as we have seen quite often. Some sectarian and tribal leaders consider it their religious and moral duty to kill in the name of religion with the ultimate objective of attaining and enhancing their political profile. Gullible clusters, dissatisfied with their social injustice and bad governance, begin to follow such insidious pathways. Like the erstwhile Deobandi ideologues, the Barelvi clerics are now exploiting these grievances in order to increase their political weight and relevance. In fact, this factor that has mostly been used to swell the numbers of the TLP at the beck and call of the late Khadim Rizvi. His son and heir to his legacy follows the suit after his death. Hafiz Saad Hussain Rizvi, was

27 TLP World , "Allama khadim Hussain rizvi about shia," YouTube, October 4, 2019, https://www.youtube.com/watch?v=n3R6DLcyRv8.

${ }^{28}$ Shakeel Qarar, "FIR registered against ASWJ leader, party workers," Dawn, February 16, 2015. 
Recent Upsurge in Sectarianism in Pakistan: Understanding the ...

released in September 2021 from the KotLakhpat Jail, ${ }^{29}$ once his name was removed from the Fourth Schedule of the Anti-Terrorism Act, 1997. His release from prison was celebrated among the TLP ranks, terming it a good omen that the party was on the 'righteous path.'

The failure of other Barelvi groups to achieve their political goals through peaceful activism has also led to a political vacuum that seems to be filled in by the TLP so as to assert its presence. Altogether, Pakistan is facing a new wave of sectarian threat in the shape of Barelvi religious exclusivism that targets Muslim and other non-Muslim minorities. In fact, the ultraright parties have provided the impetus for this renewed sectarian tension much to the discomfort of both state and society. A huge part of their agenda revolves around a sectarian narrative underpinned by sheer violence and intimidation. After all, it was the Deobandi and Barelvi organizations, as well as the Ahle Hadith, that organized the three Azmati-Sahaba rallies in Karachi in September of 2020. This is a dangerous trend that brings to the fore the damaging role that ethno-political or religious actors can play in preaching hate and shaping inter-group conflict. Parallels can be drawn to the tactics used by hate preachers in Rwanda, like Hasan Ngeze, a former Editor in Chief of the Kangura newspaper. Hasan Ngeze was charged by the Trial Chamber of the ICTR with counts of direct and public incitement to commit genocide, as he knowingly, with his consent and under his direction, published certain material in Kangura used to unleash genocide against Rwanda's ethnic Tutsi minority. ${ }^{30}$ In many of his published material, he incited to kill or cause injury to Tutsis, and persecute certain members of the Hutu majority that protected their Tutsis peers. In fact, he called for Tutsis extermination in interviews and radio broadcasts with Radio Television Libre des Mille Collines and Radio Rwanda. When hate speech was practiced in Rwanda, the principles of intergroup rivalry came into effect. Soon, people who

\footnotetext{
${ }^{29}$ Imran Gabol, "TLP chief Saad Hussain Rizvi released from jail," Dawn News, November 18, 2021, https://www.dawn.com/news/1658810.

${ }^{30}$ Hassan Ngeze's indictment confirmed, (United Nations International Residual Mechanism for Criminal Tribunals, 1997), https://unictr.irmct.org/en/news/hassanngezes-indictment-confirmed.
} 


\section{Maheen Ahmad}

were otherwise friendly to one another, even if there were neighbors, were looking at each other with suspicion. Hasan Ngeze, therefore, had an undisputed role in the Rwandan civil war of 1990-94, which culminated in a horrific genocide and is recorded in time as one of the worst cases of ethnic violence in world history. ${ }^{31}$ In little over one hundred days, more than eight hundred thousand Rwandans had lost their lives. ${ }^{32}$ An in-depth study on the tactics used by Hasan Ngeze to spur on extremist elements of the Hutu tribe to target members of the Tutsi community ${ }^{33}$ reveals that such hate preaching tactics are critical in sparking conflict between two groups; it is a cause of alarm when similar tactics are practiced in Pakistan. ${ }^{34}$

It is important that we introspect why ultra-right parties in Pakistan would be interested in perpetuating inter-group conflict. There is an element of political dynamics of sectarian violence in Pakistan. Many of the banned sectarian organizations first participate in electoral politics. They contest elections either independently or through alliances with other mainstream parties and at times, under the disguise of different names. This eventually gives them political legitimacy. ${ }^{35}$ Their narrowly understood and exclusive politics gets space in religious sloganeering. At times, such religious scholars/clergy challenge the moral authority of the national leadership by questioning their religious credentials. For instance, the TLP demanded from the government of Prime Minister Imran Khan to oust the French ambassador, but berated the government for playing into the hands of the Western agenda and not handling the caricatures incident well. This testifies to this form of totalitarian tactics in the name of defending

\footnotetext{
${ }^{31}$ Natalia Ojewska, "Rwanda genocide: 'I am a mother - I killed some children's parents'," BBC News, June 15, 2020.

${ }^{32}$ Ojewska, "Rwanda genocide,"

${ }^{33}$ Ibid.

34 "Ngeze, Hassan," The Hague Justice Portal, accessed November 21, 2021, https://www.haguejusticeportal.net/index.php?id=8415.

${ }^{35}$ Rana, The Militant, 159.
} 
Recent Upsurge in Sectarianism in Pakistan: Understanding the ...

Islam. ${ }^{36}$ This tendency in the religious groups holds subterranean qualms. On the other hand, the government is being criticized for not handling such extremist elements with an iron hand. Instead, they are obliged by multiple appeasement strategies and bargaining concessions. ${ }^{37}$

This modus operandi can be traced back to the Lal Masjid saga of 2007, when before the government took action, its clergy was consistently appeased while they acted as vigilantes in the nation's capital. ${ }^{38}$ Consider also how in a turn of events, following an agreement between Imran Khan's government and the TLP party's leadership in 2021, TLP was delisted as a proscribed organization from the First schedule of the AntiTerrorism Act, 1997. This is considered as a sign of concession that TLP members continue receiving, despite having caused direct harm to the state's apparatus.

Social psychology dictates that individuals attempt to acquire more power by reducing the space of their competitors and intensifying the rivalry so as to deny space to their rivals. Over the years, entities and groups have used violence against the religious other as an attempt to marginalize their competitors or perceived rival. For example, the street activism of some of the Barelvi groups has applied this strategy time and again, and with assured results. Firstly, Barelvi groups complained they were sidelined in the past and wanted to reclaim political space, commensurate with their role in the society. ${ }^{39}$ One of their reported grievances has been that Deobandi school of thought received state patronage during the Zia-ulHaq era. Secondly, Barelvi groups have repeatedly contended that they are frustrated given the frequent attacks on their places of worship by

${ }^{36}$ Asad Hashim, "Pakistan: TLP Protestors Free Abducted Policemen After Violence," Al Jazeera, April 19, 2021.

${ }^{37}$ Muhammad A. Rana, "Perils of sectarianism," Dawn, October 4, 2020.

${ }^{38}$ Zahid Hussain, "The Legacy of Lal Masjid," Dawn, July 13, 2017

${ }^{39}$ Maheen Ahmad, "Rise of Barelvi Extremism: Policy Options for Pakistan," IPRI Policy Briefs, May 2021, xx, https://ipripak.org/rise-of-barelvi-extremism-policy-options-forpakistan/. 


\section{Maheen Ahmad}

extremist Sunni groups like Lashkar-e-Jhangvi. ${ }^{40}$ A greater show of strength is intended to enhance the security of Barelvi followers. Thirdly, as Barelvi doctrine attaches central importance to the veneration of the Holy Prophet (Pbuh), it owns a deep-seated sense of obligation to defend the Prophet (pbuh), which can in turn, sometimes lead to over-zealous, even violent behavior. It is this last factor that has mostly been used to swell the numbers of the TLP at the beck and call of late Khadim Hussain Rizvi. As mentioned above, the failure of other Barelvi groups in achieving their political goals through peaceful activism created a power vacuum that was exploited by the TLP to assert its presence. ${ }^{41}$

\section{Conclusion and Recommendations}

This paper is attempted to understand whether the Sunni-Shia divide could be considered a case of intergroup rivalry as the embers of hate continue to be stoked. We can see that there has been a renewed effort of rightwing parties to pit Muslims against each other, differentiating between the righteous and the ones that are not perceived as such. In some ways, it could be the nefarious usage of so-called majoritarianism to seek advantages at the very expense of minorities and plural communities. Drawing upon speeches and teachings of religious clerics belonging to the right-wing parties, it is noticeable that the clerics incite hatred against anyone that does not belong to their own group and avoid subscribing to their fold. What is worrisome is the extent to which people listen to such exclusive and incriminatory discourse. Studies lend support to the theory that individuals attach great emotional attachment to the preaching and teachings of religious leaders of their respective sectarian groups. ${ }^{42}$ Such religious groups' play a critical role in developing outward perceptions of individuals of outgroups and those who are of a different sect. That is why they have a greater responsibility to be careful with their teachings and sermons. They definitely enjoy a unique position where they can discourage sectarian rivalry between individuals with different religious

\footnotetext{
${ }^{40}$ Ahmad, Rise of Barelvi Extremism: Policy Options for Pakistan.

${ }^{41}$ Ibid.

42 Jamil and Sohail, "Group Conformity," 10.
} 
Recent Upsurge in Sectarianism in Pakistan: Understanding the ...

ideologies and promote a sense of inter-faith and sectarian harmony. However, this is not the case. Religious leaders are exacerbating a rather subtle division between Shia and Sunni Muslims in Pakistan. What they are doing is the deliberate manufacture of new religious divisions. Nonetheless, if momentum by the ultra-right elements is sustained, we are at a risk of perpetuating a serious inter-group conflict involving multitudes and with no end in sight. As the Rwandan case study shows, a situation can become ugly and destructive in a mere number of days.

What makes this wave of anti-Shia sentiments particularly dangerous is because Pakistan has, to a great extent, become an arena of radicalized forces and groups. A country with a bulging youth population, a majority of them are unemployed and feeling vengeful of their plight, may encounter the risk in which the society falls prey to internecine warfare propped up by religious dissension of unnecessary dimensions. Already two in three from among the Pakistanis surveyed by Pew in 2015, consider these Shia-Sunni tensions to be real and threatening the very core of their polity. ${ }^{43}$ The situation can become even more difficult because Barelvi organizations have also adopted sectarian hues in their political dogma and emergence of such entities with extremist agendas in the political scene should be avoided. The government cannot afford the resurgence of sectarian conflict of any kind in the country, especially having successfully clamped down on major sectarian nexus in the past. ${ }^{44}$ Any rhetoric or activity that may involve inter-sect violence would be highly detrimental for the peace and interfaith harmony of the Pakistani society and so. It is the government's responsibility to ensure that ultraright parties use their freedom of speech responsibly. Moreover, the failure of civil society and government to address the drivers and fundamental causes of religious conflict will result in further social polarization on religious and sectarian grounds. As such, need of the hour is addressing this emerging threat with a comprehensive national strategy.

\footnotetext{
${ }^{43}$ Niloufer Siddiqui, "Sectarian Violence and Intolerance in Pakistan," Middle East Institute, May 27, 2015.

${ }^{44}$ Ahmad, Rise of Barelvi Extremism: Policy Options for Pakistan.
} 


\section{Maheen Ahmad}

The crux of the strategy should be discouraging sectarianism actively by improving the writ of the state and addressing the socioeconomic grievances of the masses.

To that end, the following recommendations may be worth considering.

- It is of highest importance that the government must establish and maintain state writ in the face of any extremist elements, especially those that attempt to adopt agitational and violent politics in the country.

- What will help in maintaining state writ is a mutually agreed national definition of extremism. The parliament needs to debate, construct and legalize a comprehensive definition of extremism and hate-related crimes like sectarianism. The goal is to avoid broad and open ended interpretations of theology and their political misuse, from which perpetrators are absolved from the law. The definition should be supplemented with a metric of the different types of extremism, with a special focus on how sectarianism constitutes as extremism, and may be further charged as criminal within the jurisdiction of the law.

- Banning radical entities cannot be considered a sustainable solution. It should not be expected that an organization, which is at its very core sectarian and violent, will change its ideology overnight. There is always a risk of banned sectarian outlets and radical entities to resurface and instead of being encouraged to come into mainstream, they get pushed towards splinter parties. In the past, Pakistan has seen many radical groups go into hibernation but once the crackdown of extremist entities is over, they re-emerge.

- No sectarian organization with foreign affiliation should be allowed to propagate its sectarian ideology in the country. As such, the funding channels of sectarian organizations from their foreign sponsors should be choked. 
Recent Upsurge in Sectarianism in Pakistan: Understanding the ...

- Although there was a crackdown on extremist entities, Pakistan has thus far lacked a coordinated effort to tackle the underlying drivers of extremism. Faith and sect-based discrimination and marginalization may remain a pervasive phenomenon in Pakistan, unless the government addresses the majoritarian mindset and deeprooted hate narratives that are deeply embedded in society. It is these very narratives that go onto fueling religious bigotry. The problem is not only that the ultra-right wing parties are spewing hate, but that the population and masses are ready to listen. They are keen on acting upon the instructions of their leaders, even if it requires violence. That explains why unsurprisingly, so many of the TLP mobs recently turned violent. To solve this, there needs to be a concentrated effort towards introducing an education curriculum that nudges the society towards embracing tolerance, pluralism and the diversity of beliefs and practices. Ethnic and religious particularism erodes national identity. Moreover, it would be a worthwhile effort for the state to monitor sectarian and extremist thinking in educational institutions, including respective seminaries. Sectarian tendencies should be aggressively discouraged through a ban on hate speech and written content in the shape of inflammatory pamphlets that stoke the fire of sectarian hatred. We may be wellplaced in remembering that the bans exist, but enforcement may not. 